\title{
Tourism Stocks in Times of Crises: An Econometric Investigation of Non-macro Factors ${ }^{1}$
}

\author{
Anastasios Zopiatis ${ }^{1}$, Christos S. Savva², Neophytos Lambertides ${ }^{3}$ \\ and Michael McAleer ${ }^{*}$
}

\author{
1Department of Hotel and Tourism Management, School of Business and Economics \\ Cyprus University of Technology, Cyprus \\ ${ }^{2}$ Department of Commerce, Finance and Shipping, School of Business and Economics \\ Cyprus University of Technology, Cyprus \\ ${ }^{3}$ Department of Commerce, Finance and Shipping, School of Business and Economics \\ Cyprus University of Technology, Cyprus \\ ${ }^{4}$ Department of Quantitative Finance \\ National Tsing Hua University, Taiwan \\ ‘michael.mcaleer@gmail.com
}

\begin{abstract}
Following the recent terrorist attacks in Paris, the European media emphatically pronounced that billions of euros were wiped from tourism related stocks. This comes at a troublesome time for the tourism industry, in the midst of a global financial crisis, and the unpredictable rise of radical Islamic ideologies, which have caused chaos in the Middle East and Europe. The relationship and vulnerability of the industry to non-macro incidents have been well documented in the literature, mostly in theoretical terms. Nevertheless, the quantifiable impact of such events on tourism-specific stock values, both in terms of returns and volatility, received much less attention. With the use of an econometric methodology, the paper aims to enhance our conceptual capital pertaining to the effects of such possibilities on five hospitality and tourism stock indices. The empirical findings are of interest to stakeholders at all echelons of the spectra of the tourism and financial industries
\end{abstract}

Keywords: Tourism, Terrorism, Stock Market, Event Study, GJR, Econometric Modeling.

JEL: C21, C58, G01, H12, Z32.

\section{Introduction}

November 13th, 2015. Paris came under attack from radical Islamists, resulting in the death of 130 individuals from at least 26 countries. The perpetrators, believed to be ISIS related, deliberately attacked sport, leisure and entertainment venues, all related to the tourism industry, in their attempt to cause mass casualties and strike fear in the heart of Europe. The following day, financial markets suffered extensive losses, with estimates suggesting that more than $€ 2 \mathrm{bn}$ had been wiped off European travel and hotel shares (Wearden \& Allen, 2015).

A similar scenario was repeated immediately following the March 22nd, 2016 Brussels attacks at the Zaventem International Airport and the Maelbeek subway station, again tourism related targets,

\footnotetext{
${ }^{1}$ For financial support, the fourth author acknowledges the Australian Research Council and the National Science Council, Ministry of Science and Technology (MOST), Taiwan. Michael McAleer is University Distinguished Research Professor at the Institute for Social and Economic Sciences (ISES), Dhurakij Pundit University (DPU), Bangkok, Thailand.
} 
with European stocks experiencing more heavy losses (Smout, 2016). Both events unequivocally demonstrated the diachronic vulnerability of tourism related stocks to acts of political instability, especially terrorism. Nevertheless, the specificities of this vulnerability are still a barren landscape, thus necessitating the full attention of tourism industry stakeholders.

Tourism is a multi-billion global social phenomenon with implications for almost all aspects of modern societies. Projections by the World Tourism Organization (WTO, 2014) portray a promising picture for the sector, with more than 1.8 billion individuals traveling until the year 2030 . Unfortunately, the values and norms governing day-to-day tourism operations, along with its global exposure and volatile response qualities, portray the industry as a 'convenient' target for acts of political instability. Moreover, the post-event generated global coverage, fueled in recent times by the 24-hour news media frenzy, the internet, and social networks, provides unprecedented publicity to such events, thereby influencing geostrategic interests, regional and global policies and, of vital importance to the tourism industry, travel attitudes and behavior.

There is an extensive literature on the relationship between incidents of political instability (such as terrorism and wars) and 'Acts of God' with the tourism industry. For the past forty years, terrorism surfaced as the industry's primary 'adversary', with a multitude of terrorist groups targeting its superstructure and infrastructure as a vital mean to promote their own ideological agendas. In the early 1970's, the European continent experienced severe forms of transnational terrorism attributed to the rise of numerous Marxist/Leninist extremist groups, whereas in the Middle-East the issue of Palestine instigated the rise of groups, most notably the Popular Front for the Liberation of Palestine (PFLP), which extensively used aircraft hijackings in their revolutionary struggles (Sönmez, 1998). During that turbulent period, airports, commercial aircraft, hotels, public mass transportation systems, restaurants, cruise liners, leisure venues, and nightclubs, became 'an ideal target of choice', causing a severe loss of human lives, including innocent bystanders and tourists.

Following the end of the Cold War in 1991, the global community experienced the rise of Islamic fundamentalism, with Al Qaeda orchestrating, a decade later, the devastating September 11th, 2001 attacks in the USA, with detrimental effects for the tourism industry (Goodrich, 2002). This group, responsible for hundreds of attacks which destabilized the Middle East and other regions of the world for almost a decade, was gradually restrained, following two major War conflicts, in Iraq (2003-2011) and Afghanistan (2001-2014), and the death of Al Qaeda's founder, Osama bin Laden, in 2011. Following Al Qaeda's demise, the Islamic State (IS, also known as ISIS or ISIL) surfaced as the most formidable terrorist group in recent times. By espousing an ultra-radical ideology based on an extremist interpretation of Islam, which promotes religious violence, the Islamic State (IS) is responsible for numerous barbaric acts to terrorism, most of which have directly targeted tourists.

Attacks directed by and/or linked to the Islamic State, include, among others, the Paris attacks (November 13, 2015), the Tunisia Beach resort attack (June 26, 2015), which cost an estimated $\$ 515$ million in lost revenues (Cadavez, 2016), and the downing of a Russian passenger jet over Sinai, Egypt (October 31, 2015) which killed 224 tourists departing from their vacations from Sharm el Sheikh. The attack outside the popular Red Sea resort had an estimated revenue loss of $\$ 843$ million just in the first three months following the incident (Kholaif, 2015).

In addition to terrorism incidents, tourism suffered severely by unanticipated 'Acts of God' and pandemics, and other incidents of political instability, such as War conflicts and economic crises. The literature suggests that such unexpected incidents negatively affect the 'economics' of tourism, in a multitude of ways, since the pure essence of the industry, unfortunately, makes it a 'probable first casualty' in such eventualities. Indicatively, Chen et al. (2007) suggest that the Severe Acute Respiratory Syndrome (SARS) epidemic outbreak of 2003 caused an approximate $29 \%$ decline in Taiwanese hotel stock prices, whereas the 2004 Indian Ocean Tsunami caused the death of 300,000 individuals, including thousands of western tourists, at an estimated economic cost of $\$ 10$ billion (Sharpley, 2005). In terms of financial crises, numerous studies (Chen, 2007; Chen, Kim, \& Kim, 2005) have investigated the impact of macro variables on hotel stock returns, with Brent Ritchie, Molinar, and Frechtling (2010) suggesting the enhanced vulnerability of the industry during economic recessions compared with other economic sectors. 
Responding to the urgent need for conceptual clarity, scholars investigated the relationship between tourism and incidents of instability, with emphasis on terrorism, from an array of different perspectives. Aligned with the characteristics and narrative of each era, scholars measured the impact and effect of events for the industry (Enders, Sandler, \& Parise, 1992; Saha \& Yap, 2014), developed destination-recovery strategies (Blake \& Sinclair, 2003), proposed destination-image restoration tactics (Avraham, 2013), introduced holistic strategic disaster/crises management approaches (Mansfeld, 1999), and propounded destination-specific anti-terrorism strategies (Paraskevas \& Arendell, 2007). Despite the extensive coverage, numerous scholars (Chan, Lim, \& McAleer, 2005; Paraskevas, Altinay, McLean, \& Cooper, 2013) have argued that the severity and urgency of the topic, especially due to the substantial cost increase of conducting day-to-day business (Chen \& Siems, 2004), necessitates research that expand the collective conceptual capital in metrics and controls, both of which are essential in managing knowledge in tourism crises.

A foray into the most popular academic databases reveals the scarcity of studies measuring the effects of such incidents on financial markets, in general, and the hospitality and tourism related stocks and indices, in particular (Chen et al., 2007; Drakos, 2004). Despite some notable attempts to investigate partially tourism-related topics, mostly in the sphere of macro-incidents (see, for example, Chen, 2011; Chen, Jang, \& Kim, 2007; Zheng, Farrish, \& Kitterlin, 2016), the existing literature fails to respond convincingly to a number of questions surrounding the behavior and reaction of hospitality and tourism-specific stock indices following major non-macro incidents.

This subtext, which cannot be ignored, suggests that the susceptibility, exposure and reaction (behavior) of market-specific stock sectors to pertinent incidents may significantly differ based on the type, strength and perceived repercussions of the event (Aslam \& Kang, 2015; Chesney, Reshetarb, \& Karamana, 2011). Indicatively, Chesney et al. (2011) suggested that the insurance and airline industry sectors are more vulnerable to terrorism, whereas the banking sector is mostly affected by financial downturns. Moreover, they argue that financial markets react differently to unpredictable natural catastrophes (Acts of God) compared with terrorism-related incidents, especially in the postevent period.

Echoing similar reasoning, Brounrn and Derwall (2010) posited that industries directly affected by an incident (for example, the airline industry in the aftermath of the September 11th, 2001 attacks in the USA) exhibit stronger reactions that may not be adequately portrayed in generic market indices. Moreover, Essaddam and Karagianis (2014) introduce a regional aspect to the 'equation' by suggesting that the attributes, and perceived national risk (Chen, 2007), of the specific country suffering the attack may influence the overall impact. It is, therefore, imperative that empirical investigations focus their attention to the behavior of specific sectors, rather than following the norm of investigating the overall stock market's sentiment, such as the effect on the FTSE 100 index.

Responding to this emerging need, this paper aims to enhance the existing conceptual capital by econometrically investigating five hospitality/tourism stock indices' reactions to 150 , manually compiled, incidents (Acts of Terrorism, 'Acts of God', War conflicts) covering the period from January 2000 until February 2016. Moreover, the inclusion of additional variables aims to enhance our understanding by addressing pertinent questions, such as whether the characteristics of each incident affects stock reaction (returns) and volatility (uncertainty or risk) (see, McAleer, 2015). Empirical findings of importance to stakeholders should pave the way for meaningful contributions and interventions to current industry practices, both at the operational and strategic levels.

\section{Non-Macro events of Instability and Stock Markets' Behavior}

Scholars investigating the impact of shocks to stock markets classify incidents into macro and nonmacro, with the first being more 'popular' in research endeavors. As suggested by Chen (2007, p. 992), macro variables “...generally consist of industrial production growth rate, inflation rate, growth rate of money supply, yield spread, changes in unemployment rate, growth rate of imports and changes in exchange rates." In contrast, non-macro variables, the focus of the current paper encompass, among others, natural disasters, Wars, and terrorist attacks (Chen, 2007). Chen's study concluded that the impact of macro-variables on hotel stocks is far more clear and decisive, compared 
with non-macro variables, since other externalities, such as the country's risk, may influence investors' expectations.

Studies exploring the impact of non-macro events associated with terrorism and natural catastrophes on financial markers reach a consensus in suggesting the existence of an adverse effect (Arin, Ciferri, \& Spagnolo, 2008; Charles \& Darne, 2006; Eldor \& Melnick, 2004; Nikkinen \& Vähämaa, 2010). Despite the fact that the negative direction of the relationship is unambiguous, the externalities of the event's magnitude and the post-event recovery period are contested issues. Indicatively, Chesney et al. (2011) suggested that two- thirds of the terrorists' attacks investigated in their study caused a significant negative effect on stock markets. Charles and Darne (2006) argued that the shock, both permanent and temporary, is extensive, whereas Brounrn and Derwall (2010) posited that terrorist attacks produce mildly negative price effects on stock market prices. It is, therefore, prudent to conclude that methodological heterogeneities, the specificities of the actual event, and the target-destination idiosyncrasies, influence the overall impact; a notion that is also supported by Essaddam and Karagianis (2014).

The stock market's recovery period following an incident has also captured the attention of scholars. Overall, research suggests that such incidents cause drastic, but short-term transitory effects on stock markets, especially on the first day, with recovery in most cases occurring within one to two days (Brounrn \& Derwall, 2010; Chesney et al., 2011; Drakos, 2010). Kollias, Papadaumou and Stagiannis (2011), by contrasting the stock behavior following the attacks in Madrid (2004) and London (2005), suggested that recovery may be affected by both the type of the attack, and the promptness and adequacy of the country's institutional responses, an argument that is supported by Essaddam and Karagianis (2014), and Aslam and Kang (2015). With regard to volatility, the literature suggests a significant increase for up to 15 days following the incident (Drakos, 2004; Essaddam \& Karagianis, 2014), with some suggesting that this effect is larger in emerging markets (Arin et al., 2008). The event's specific characteristics have surfaced as a vital element of stock market reaction. Indicatively, Brounrn and Derwall (2010) suggested that terrorism incidents have a greater economic impact, especially on the day of the event, compared with unanticipated natural catastrophes, whereas Chesney et al. (2011) argued that the latter exhibit longer post-event impact due to the delay in measuring their actual catastrophic effects. Moreover, Aslam and Kang (2015) posited that the location, type, intensity (measured by the number of fatalities), and tactics of the attack affect stock market behavior, whereas Essaddam and Karagianis (2014) argued that the geographic location in which the attack occurred influenced its overall impact. Kollias et al. (2011), by comparing the attacks in Madrid (2004) and London (2005), suggested that London's market was able to rebound faster due to the fact that the attackers were suicide bombers, so that the imminent security danger ceased to exist. From a different perspective, Zussman and Zussman (2006) argued that markets react differently to Israeli's controversial policy of assassinating Palestinian political and military leaders, with the first causing strong negative reactions, while Eldor and Melnick (2004) suggested that Palestinian attacks on transport infrastructure caused a transitory effect on the Tel Aviv Stock Exchange (TASE).

As previously noted, the country's institutional response in such eventualities also plays a significant role in post-event market behavior. Countries whose financial institutions were equipped with informed contingency plans were able to mitigate the negative effects of such incidents (Kollias et al., 2011), with the United Kingdom being a perfect example, following the 2005 London bombings. The same scholars argued that contingency plans, developed in the aftermath of the September 11th, 2001 attacks in the USA, involving the vast majority of the country's financial stakeholders, helped mitigate the negative effects, thereby ensuring smooth trading in the United Kingdom financial markets.

In the hospitality literature, notable studies have been conducted by Ming-Hsiang Chen, mostly in the Chinese, Japanese and Taiwanese business settings. His conceptual reasoning, which revolved around the investigation of macro and non-macroeconomic variables, particularly hotel performance measurements, profitability, and stock performance (Chen, 2007; 2011), was an extension of Barrows and Naka's (1994) seminal work, which investigated the influence of macroeconomic variables on 
restaurant and hotel stock returns of companies in the USA. Espousing a similar reasoning, others investigated the impact of mostly macroeconomic variables on hospitality and tourism-related stock indices. Indicatively, Wong and Song (2006) exemplified the dependence of hospitality stock indices in the USA on macroeconomic variables, with interest rates being the most significant, whereas Leong and Hui (2014) investigated pertinent topics in Singapore. Despite the fact that findings provide evidence of dependencies, at different levels and degrees, for both macro and non-macro incidents, other externalities may have a confounding effect on this relationship.

\subsection{Econometrics and Pertinent Studies}

Econometric modeling has received considerable attention during the past twenty years, with applications ranging from forecasting cycles and risk, assessing and analyzing the impact of events, and modeling turning points and directional changes. The diverse nature of research using econometric techniques in the tourism literature has been highlighted by Song and Li (2008), who attempted to expand our horizons into new 'uncharted' territories of empirical investigations. Despite the newfound popularity, to the best of our knowledge, no tourism-related study has ever used advanced econometrics in investigating the effect of political instability incidents to the industry's stock indices. The vast majority of related studies, which have used extensively econometric techniques in their analysis, derive from the generic business, finance and economics literature.

Indicatively, Drakos (2010) used pooled panel ARCH to model the effects of terrorism activities on the investor's psychosocial sentiment. Chesney, Reshetarb, and Karamana (2011) used a filtered GARCH-EVT approach to study the impact of incidents on stock behavior. Kollias, Papadaumou and Stagiannis (2011) applied the GARCH model to investigate the effects of two major terrorist incidents occurred in the European continent, whereas Essaddam and Karagianis (2014), using GARCH, examined the volatility of stock returns following a terrorist event. Peren, Ciferri, and Spagnolo (2008) explored the effect of terrorist attacks on financial markets which, according to the authors, "... has not received the same level of attention (compared to the short-term effects on major macroeconomic variables)" (p. 164). It is important to note that despite the methodological similarities, the data used in the studies exhibited heterogeneities that restrict any attempt to reach definite and generalizable conclusions.

\section{Methodology}

The primary purpose of the paper is to measure econometrically the effects of instability incidents (Terrorism, 'Acts of God', and War Conflicts) on hospitality/tourism stock indices that are currently trading in international stock markets. In particular, five hospitality/tourism-related stock indices from different regions, namely FTSE Travel and Leisure World, FTSE Travel and Leisure Asia Pacific, FTSE Travel and Leisure Australia, FTSE Travel and Leisure America, and FTSE Travel and Leisure Europe, were selected for analysis from Thomson Reuters Datastream. These five indices (henceforth $\mathrm{H} / \mathrm{T}$ indices) cover the vast majority of hospitality, tourism and leisure organizations from around the globe, and so are considered to be ideal for our purposes. Their selection was also based on numerous study-specific criteria, such as the region covered, years of data coverage (going back to 2000), and volume and content. Moreover, the inclusion of additional variables may further dissect this relationship, thereby enhancing the existing body of knowledge. In particular, variables such as the geographic location of incidents, fatalities caused, type and place of the attack, affiliation of the perpetrators, and subsequent media exposure, may provide a more comprehensive view of stock market reaction to such eventualities.

Therefore, reflecting upon the extant literature and addressing the primary purposes of the paper, the following seven research questions are postulated:

RQ1a: Do terrorist attacks have a significant effect on $\mathrm{H} / \mathrm{T}$ stock indices (that is, returns and volatility)? $R Q 1 b$ : Do 'Acts of God' have a significant effect on $\mathrm{H} / \mathrm{T}$ stock indices (that is, returns and volatility)? $R Q 1 c$ : Do War conflicts (day of declaration) have a significant effect on $\mathrm{H} / \mathrm{T}$ stock indices (that is, returns and volatility)?

RQ2: Does the geographic location of the incident of instability affect $\mathrm{H} / \mathrm{T}$ stocks (that is, returns and volatility) in the regional and/or global financial markets? 
$R Q 3:$ What is the impact on $\mathrm{H} / \mathrm{T}$ stocks from incidents causing tourist fatalities? Is there a difference according to the number of fatalities (severity)?

RQ4: What is the impact on $\mathrm{H} / \mathrm{T}$ stocks from incidents involving attacks on tourism infrastructure / superstructure (such as restaurants, hotels, and airports)?

RQ5: Does the type of attack [perpetrators killed from suicide attacks or apprehended during the attack, versus perpetrators who were later apprehended or are still at large] influence the effect on $\mathrm{H} / \mathrm{T}$ stock indices (that is, returns and volatility)?

RQ6: Does the affiliation of the attackers (known terrorist organization versus Lone Wolves) influence the effect on $\mathrm{H} / \mathrm{T}$ stock indices (that is, returns and volatility)?

RQ7: Does media exposure influence the effect on $\mathrm{H} / \mathrm{T}$ stock indices (that is, returns and volatility)?

For the empirical analysis, a database including 150 incidents occurring in the World after 2000 was manually compiled from various internet sources. For each incident, data pertaining to its characteristics, namely date, category of the event (Terrorism, 'Acts of God', War conflict), geographic location (country / region), tourist fatalities (number), infrastructure/superstructure involved (tourist related, such as hotels, restaurants, and airports), type of attack (perpetrators killed or apprehended during the attack versus perpetrators that were later apprehended, or are still at large), affiliation of the attack (known terrorist organizations versus Lone Wolf attacks), and media exposure, were collected. It is important to indicate that each incident included in the database had to be verified from at least two independent sources. Note that some variables are not related with all types of incidents (such as Acts of God).

\section{Econometric Models}

\subsection{Impact of Various Events on Returns and Volatility}

As previously stated, the paper investigates the sensitivity of returns and volatility of $\mathrm{H} / \mathrm{T}$ indices in reaction to 150 study-specific incidents. In particular, and following the discussion in the previous section, two questions are addressed:

- Is there a change in the returns, considering the reaction of the market during and after the event/shock?

- Is there a change in the volatility considering the reaction of the market during and after the event/shock?

Subsequently, the GJR specification of Glosten, Jagannathan and Runkle (1993) is used to model the autoregressive returns (denoted $r_{t}$ ) augmented by the appropriate dummies and their conditional variance (volatility), denoted $h_{t}$ (also augmented by appropriate dummies). Moreover, the returns were modelled by an autoregressive process of order 1 to account for possible autocorrelation ${ }^{2}$ :

$$
r_{t}=c+\varphi_{1} r_{t-1}+\theta_{j, \tau} d_{j, t, \tau}+u_{t}
$$

and the conditionally heteroskedastic error term, $u_{t}$, was assumed to follow the asymmetric process according to the GJR specification (see, McAleer, 2014):

$$
\begin{aligned}
& u_{t}=\sqrt{h_{t}} e_{t}, \\
& h_{t}=\omega+\gamma_{1} e_{t-1}^{2}+\alpha_{1} e_{t-1}^{2}\left(e_{t-1}<0\right)+\beta_{1} h_{t-1}+\xi_{j, \tau} d_{j, t, \tau} .
\end{aligned}
$$

in which the parameters $\gamma_{1}$ and $\alpha_{1}$ are positive, and $\beta_{1}$ lies in the range $(-1,1)$.

The exponential GARCH (EGARCH) model of Nelson (1991) is also asymmetric, but the underlying stochastic process has no regularity conditions, and hence has no asymptotic statistical properties (McAleer \& Hafner, 2014).

The variables denoted $d_{j, t, \tau}$ are dummy variables indicating the existence of an event described in research question $j(j=1,2, \ldots, 7)$ during period t. It is equal to 1 if there is such an event, and 0 otherwise. The index $\tau$ indicates an observation window:

\footnotetext{
${ }^{2}$ The innovations, $e_{t}$, are assumed independently and identically distributed. In order to account for non-normality in the returns shocks, the parameters were estimated by quasi-maximum likelihood (QML).
} 
1. Concurrent event period $(\tau=0)$ captures the effects of the event on returns and volatility on the same date.

2. A period after the event $(\tau=1,2,3 \ldots)$ captures the effects of the event on returns and volatility the following days. ${ }^{3}$

If these dummies are significant, it can be inferred that the events described in the research questions have impacts on returns and/or volatility.

As for the remaining variables, they are explained as follows: In equation (1), the coefficient $\varphi 1$ captures the lagged effects of the returns (that is, whether the previous day's returns affect current returns), while in equation (3), the coefficients $\alpha_{1}$ and $\beta_{1}$ capture the short-run persistence and contribution to the long-run persistence of volatility. Finally, the coefficient $\gamma_{1}$ captures the asymmetry in volatility (that is, whether negative shocks have a greater impact on volatility compared with positive shocks of the same magnitude).

\section{Empirical Findings}

5.1 Research Questions 1(a,b,c): Terrorist Attacks, 'Acts of God', and Wars impact on H/T Stock Indices

The first research question investigates whether terrorist attacks have a significant effect on hospitality / tourism stocks indices, both in terms of returns and volatility (RQ 1a). As shown in Table 1 , the results indicate a significant negative impact on $\mathrm{H} / \mathrm{T}$ stock indices in all regions, except Australia. In all cases, the indices were not affected by the specific event on day $t$ (the day of the terrorist attack), but they dropped significantly on the following day. In comparison, the next day drop of European indices was considerably larger $(-0,360 ; p=0,007)$ compared with the American, Asia Pacific and World indices. With regard to Australia's index, which revealed insignificant results, a plausible explanation may revolve around the country's isolated geographical location and national risk, which makes it less vulnerable and susceptible to such shocks.

When investigating the volatility caused by terrorist attacks on $\mathrm{H} / \mathrm{T}$ stock indices, with the exception of Australia, the results indicate a significant positive impact on the day of the event. In contrast, despite the volatility increases on the day of the event, the World and America indices remained unaffected on the following day. This behavior may be attributed to the different reactions of each market to specific shocks. Subsequent analysis, using impulse response functions (see the following paragraphs), suggested that both the price drop and volatility increase fully recovered to their pre-event levels 2 to 3 days following the incident. Therefore, it is prudent to suggest that the overall impact of such shocks is short term.

Table 1: Terrorism Incidents and H/T Stock Indices

\begin{tabular}{|c|c|c|c|c|c|}
\hline & WORLD & ASIA PAC & AUSTRALIA & AMERICA & EUROPE \\
\hline \multicolumn{6}{|l|}{ Results - Mean } \\
\hline \multirow[t]{2}{*}{$\mathrm{C}$} & 0,030 & 0,024 & 0,046 & 0,039 & 0,040 \\
\hline & $\left(0,040^{*}\right)$ & $(0,180)$ & $(0,050 *)$ & $(0,091)$ & $(0,426)$ \\
\hline $\operatorname{FTSE}(-1)$ & 0,096 & 0,003 & 0,017 & $-0,010$ & 0,055 \\
\hline ( $\mathrm{p}$ value) & $(0,002 * *)$ & $(0,929)$ & $(0,471)$ & $(0,502)$ & $\left(0,027^{*}\right)$ \\
\hline TERRORISM & 0,022 & $-0,105$ & $-0,127$ & $-0,069$ & $-0,126$ \\
\hline ( $p$ value) & $(0,899)$ & $(0,645)$ & $(0,297)$ & $(0,587)$ & $(0,258)$ \\
\hline TERRORISM(1) & $-0,131$ & $-0,301$ & $-0,195$ & $-0,202$ & $-0,360$ \\
\hline ( $p$ value) & $\left(0,017^{*}\right)$ & $(0,049 *)$ & $(0,128)$ & $\left(0,034^{*}\right)$ & $(0,007 * *)$ \\
\hline \multicolumn{6}{|l|}{ Results - Variance } \\
\hline \multirow[t]{2}{*}{$\mathrm{C}$} & 0,012 & 0,023 & 0,028 & 0,027 & 1,300 \\
\hline & $(0,007 * *)$ & $(0,002 * *)$ & $(0,007 * *)$ & $(0,001 * *)$ & $(0,005 * *)$ \\
\hline
\end{tabular}

${ }^{3}$ In practice, only the day after the event has an effect on either returns or volatility, so that in estimation we used only $\tau=0$ and $\tau=1$. 
Table 1, cont.

\begin{tabular}{lccccc}
$\operatorname{RESID}(-1)^{\wedge} 2$ & 0,019 & 0,044 & 0,033 & 0,021 & 0,072 \\
$\operatorname{RESID}(-$ & & & & & \\
$1)^{\wedge} 2^{*}(\operatorname{RESID}(-1)<0)$ & 0,079 & 0,048 & 0,066 & 0,094 & 0,011 \\
GARCH$(-1)$ & 0,939 & 0,925 & 0,930 & 0,941 & 0,588 \\
TERRORISM & 0,214 & 0,516 & $-0,009$ & 0,227 & 0,836 \\
$(\mathrm{p}$ value $)$ & $\left(0,014^{*}\right)$ & $\left(0,004^{* *}\right)$ & $(0,935)$ & $(0,054)$ & $(0,009 * *)$ \\
TERRORISM $(1)$ & $-0,071$ & $-0,306$ & 0,130 & $-0,009$ & 1,461 \\
$(\mathrm{p}$ value $)$ & $(0,280)$ & $\left(0,004^{* *}\right)$ & $(0,584)$ & $(0,946)$ & $\left(0,006^{* *}\right)$ \\
\hline
\end{tabular}

Note: $* \mathrm{p}<0.05 ; * * \mathrm{p}<0.01$

With similar reasoning, the paper investigated the impact of 'Acts of God', widely defined as events outside human control, such as tsunami and earthquakes, for which no one can be held responsible (RQ1b). Despite the fact that the findings exhibited an overall similar trend with terrorist attacks, certain differences are noteworthy (see Table 2). Specifically, 'Acts of God' had a significant negative impact on all five $\mathrm{H} / \mathrm{T}$ stock indices (returns) on the day of the event, which continued on the following day for the World, American and European indices. The overall effect for these indices for both days was identical, whereas the Asia Pacific and Australian indices exhibited insignificant drops on the day after the incident. With regard to volatility, the findings revealed positive impacts on the day of the event for the Asia Pacific, European, Australian and American stock indices, with the latter two also exhibiting significant increases on the following day.

Table 2: 'Acts of God' and H/T Stock Indices

\begin{tabular}{|c|c|c|c|c|c|}
\hline & WORLD & $\begin{array}{l}\text { ASIA } \\
\text { PAC }\end{array}$ & $\begin{array}{c}\text { AUSTRALI } \\
\text { A }\end{array}$ & $\begin{array}{c}\text { AMERIC } \\
\text { A }\end{array}$ & $\begin{array}{c}\text { EUROP } \\
\text { E }\end{array}$ \\
\hline \multicolumn{6}{|l|}{ Results - Mean } \\
\hline $\mathrm{C}$ & $\begin{array}{c}0,033 \\
(0,058)\end{array}$ & $\begin{array}{c}0,030 \\
(0,170)\end{array}$ & $\begin{array}{c}0,005 \\
(1,008)\end{array}$ & $\begin{array}{c}0,030 \\
(0,171)\end{array}$ & $\begin{array}{c}0,028 \\
(0,091)\end{array}$ \\
\hline $\begin{array}{l}\text { FTSE }(-1) \\
\text { (p value) }\end{array}$ & $\begin{array}{c}0,096 \\
(0,001 * *)\end{array}$ & $\begin{array}{l}-0,003 \\
(0,821)\end{array}$ & $\begin{array}{c}0,025 \\
(0,482)\end{array}$ & $\begin{array}{l}-0,005 \\
(0,548)\end{array}$ & $\begin{array}{c}0,053 \\
(0,004 * *)\end{array}$ \\
\hline $\begin{array}{l}\text { GOD } \\
\text { (p value) }\end{array}$ & $\begin{array}{c}-1,285 \\
(0,012 *)\end{array}$ & $\begin{array}{c}-0,990 \\
\left(0,026^{*}\right)\end{array}$ & $\begin{array}{c}-0,168 \\
\left(0,044^{*}\right)\end{array}$ & $\begin{array}{c}-1,167 \\
\left(0,013^{*}\right)\end{array}$ & $\begin{array}{c}-1,183 \\
\left(0,031^{*}\right)\end{array}$ \\
\hline $\begin{array}{l}\text { GOD }(1) \\
\text { (p value) }\end{array}$ & $\begin{array}{c}-1,072 \\
\left(0,017^{*}\right)\end{array}$ & $\begin{array}{l}-0,725 \\
(0,077)\end{array}$ & $\begin{array}{l}-0,159 \\
(0,672)\end{array}$ & $\begin{array}{c}-1,290 \\
\left(0,018^{*}\right)\end{array}$ & $\begin{array}{c}-1,048 \\
\left(0,044^{*}\right)\end{array}$ \\
\hline \multicolumn{6}{|l|}{ Results - Variance } \\
\hline $\mathrm{C}$ & $\begin{array}{c}0,013 \\
(0,009 * *)\end{array}$ & $\begin{array}{c}0,018 \\
\left(0,008^{* *}\right)\end{array}$ & $\begin{array}{c}1,859 \\
(0,002 * *)\end{array}$ & $\begin{array}{c}0,024 \\
(0,009 * *)\end{array}$ & $\begin{array}{l}0,029 \\
0,009\end{array}$ \\
\hline $\operatorname{RESID}(-1)^{\wedge} 2$ & 0,019 & 0,047 & $-0,030$ & 0,015 & 0,029 \\
\hline $\begin{array}{l}\operatorname{RESID}(-1)^{\wedge} 2 *(\operatorname{RESID}(- \\
1)<0)\end{array}$ & 0,081 & 0,051 & 0,099 & 0,098 & 0,121 \\
\hline GARCH(-1) & 0,945 & 0,922 & 0,567 & 0,933 & 0,913 \\
\hline GOD & $-0,356$ & 1,192 & 2,745 & 2,007 & 1,085 \\
\hline (p value) & $(0,851)$ & $(0,020 *)$ & $(0,005 * *)$ & $\left(0,011^{*}\right)$ & $\left(0,014^{*}\right)$ \\
\hline $\begin{array}{l}\text { GOD }(1) \\
\text { (p value) }\end{array}$ & $\begin{array}{c}0,615 \\
(0,757)\end{array}$ & $\begin{array}{l}-0,538 \\
(0,486)\end{array}$ & $\begin{array}{c}2,752 \\
(0,066)\end{array}$ & $\begin{array}{c}2,130 \\
\left(0,013^{*}\right)\end{array}$ & $\begin{array}{c}-1,054 \\
(0,002 * *)\end{array}$ \\
\hline
\end{tabular}

Note: ${ }^{*} \mathrm{p}<0.05 ; * * \mathrm{p}<0.0$

War conflicts (day of declaration) had a much different impact on $\mathrm{H} / \mathrm{T}$ stock indices compared with terrorism incidents and 'Acts of God' (RQ1c). In particular, the findings presented in Table 3, 
revealed that such incidents had a significant negative effect only on the World stock index $(-0,851$; $p=0,027)$ on the day following the War declaration. The findings suggest that the uncertainty surrounding such events minimize stock market shocks during the first days of the conflict. In contrast, when investigating the volatility caused by such events, the findings portrayed a much different picture since the World, American, and European stock indices exhibited a significant increase on the day after, whereas the latter (European) index also experienced a significant increase on the day of the declaration.

Table 3: Wars and H/T Stock Indices

\begin{tabular}{|c|c|c|c|c|c|}
\hline & WORLD & ASIA PAC & AUSTRALIA & AMERICA & EUROPE \\
\hline \multicolumn{6}{|c|}{ Results - Mean } \\
\hline \multirow[t]{2}{*}{$\mathrm{C}$} & 0,041 & 0,026 & 0,029 & 0,021 & 0,039 \\
\hline & $(0,025 *)$ & $(0,202)$ & $(0,282)$ & $(0,329)$ & $(0,067)$ \\
\hline FTSE(-1) & 0,098 & 0,006 & 0,011 & $-0,006$ & 0,047 \\
\hline ( $p$ value) & $(0,007 * *)$ & $(0,914)$ & $(0,914)$ & $(0,664)$ & $\left(0,025^{*}\right)$ \\
\hline WAR & 0,474 & 0,419 & $-0,456$ & 1,465 & 0,191 \\
\hline (p value) & $(0,783)$ & $(0,468)$ & $(0,584)$ & $(0,324)$ & $(0,795)$ \\
\hline WAR(1) & $-0,851$ & $-1,015$ & 0,438 & $-1,119$ & 0,288 \\
\hline ( $p$ value) & $(0,027 *)$ & $(0,109)$ & $(0,713)$ & $(0,229)$ & $(0,823)$ \\
\hline \multicolumn{6}{|c|}{ Results - Variance } \\
\hline \multirow[t]{2}{*}{$\mathrm{C}$} & 0,188 & 0,018 & 0,585 & 0,142 & 0,032 \\
\hline & $(0,002 * *)$ & $(0,002 * *)$ & $(0,007 * *)$ & $(0,003 * *)$ & $(0,008 * *)$ \\
\hline $\operatorname{RESID}(-1)^{\wedge} 2$ & 0,091 & 0,047 & 0,186 & 0,108 & 0,024 \\
\hline RESID(- & 0,419 & 0,051 & 0,275 & 0,244 & 0,121 \\
\hline \multicolumn{6}{|c|}{$1)^{\wedge} 2 *(\operatorname{RESID}(-1)<0)$} \\
\hline GARCH(-1) & 0,614 & 0,918 & 0,434 & 0,753 & 0,912 \\
\hline WAR & 9,965 & 0,120 & $-1,032$ & 9,995 & 2,078 \\
\hline (p value) & $(0,058)$ & $(0,958)$ & $(0,246)$ & $(0,083)$ & $\left(0,050^{*}\right)$ \\
\hline WAR(1) & $-0,728$ & $-0,002$ & $-0,092$ & $-1,950$ & $-0,880$ \\
\hline (p value) & $(0,010 *)$ & $(1,002)$ & $(0,833)$ & $(0,004 * *)$ & $(0,004 * *)$ \\
\hline
\end{tabular}

Note: $* \mathrm{p}<0.05 ; * * \mathrm{p}<0.01$

Additional analysis with the use of the Impulse Response Function in an AR process was conducted to predict the variable's movements given its past. This technique illustrates how the variable responds to a shock of a specific magnitude, and how long it takes to return to its original level. The findings shown in Figure 1 suggest that the shock from terrorist incidents (RQ1a) lasts for 2 to 3 trading days, a result that is consistent with the significance of the estimated (event) parameters. It can be inferred that, although the initial shock of such incidents is quite substantial for the first 1-2 days, it dies out in subsequent periods. It is important to note that the results are qualitatively similar for the rest of the estimates pertaining to 'Acts of God', and War conflicts (RQ1b and RQ1c - not presented to save space).

\section{Figure 1: Impulse Response Function}

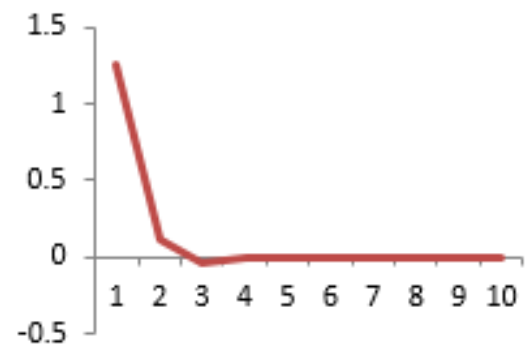




\subsection{Research Question 2 - Geographic Location of the Incident and H/T Stock Indices}

The second research question investigated whether the geographic location in terms of the five regions (Europe, America, Asia/Pacific, Australia, and Africa) of the actual attack impacts the five $\mathrm{H} / \mathrm{T}$ stock indices. As shown in Table 4, incidents occurring in America (mostly in the USA) had a significant negative impact on the World, Australian and American H/T stock indices (note the negative effect at $p<0.10$ for the Asia Pacific and Europe). Similarly, incidents occurring in Australia had a negative effect, mostly the following day, on stock indices in Asia Pacific, Australia and America, whereas European events seem to have a significant effect (negative) only on the European index $(-0,399 ; p=0,012)$ on the following day. Events occurring in Africa and Asia Pacific did not have any significant effect on any of the five indices. It is apparent that only incidents occurring in America influence negatively all $\mathrm{H} / \mathrm{T}$ indices. Moreover, the estimated coefficients suggest volatility increases (either on the same day of the shock, or on the following day) when events occur in Europe or America in almost all markets, whereas there are rather sparse spillover effects when events occur in other regions.

Table 4: Geographic Location and H/T Stock Indices

\begin{tabular}{|c|c|c|c|c|c|}
\hline & WORLD & $\begin{array}{l}\text { ASIA } \\
\text { PAC }\end{array}$ & $\begin{array}{c}\text { AUSTRALI } \\
\text { A }\end{array}$ & $\begin{array}{c}\text { AMERIC } \\
\text { A }\end{array}$ & EUROPE \\
\hline \multicolumn{6}{|l|}{ Results - Mean } \\
\hline FTSE(-1) & 0,096 & 0,008 & 0,012 & $-0,016$ & 0,054 \\
\hline (p value) & $(0,007 * *)$ & $(0,832)$ & $(0,660)$ & $(0,375)$ & $(0,051)$ \\
\hline EUROPE & $-0,022$ & 0,127 & 0,061 & 0,011 & $-0,117$ \\
\hline ( $p$ value) & $(0,906)$ & $(0,527)$ & $(0,833)$ & $(0,973)$ & $(0,055)$ \\
\hline EUROPE(1) & $-0,540$ & $-0,306$ & $-0,082$ & 0,005 & $-0,399$ \\
\hline (p value) & $(0,070)$ & $(0,253)$ & $(0,747)$ & $(0,987)$ & $(0,012 *)$ \\
\hline AMERICA & $-0,480$ & $-0,889$ & $-0,512$ & $-0,820$ & $-0,108$ \\
\hline (p value) & $\left(0,014^{*}\right)$ & $(0,063)$ & $\left(0,043^{*}\right)$ & $\left(0,034^{*}\right)$ & $(0,785)$ \\
\hline AMERICA(1) & $-0,468$ & $-0,235$ & $-0,416$ & $-0,575$ & $-0,363$ \\
\hline ( $p$ value) & $\left(0,014^{*}\right)$ & $(0,645)$ & $\left(0,014^{*}\right)$ & $\left(0,012^{*}\right)$ & $(0,067)$ \\
\hline ASIA & $-0,259$ & $-0,234$ & $-0,455$ & $-0,088$ & $-0,020$ \\
\hline ( $p$ value) & $(0,178)$ & $(0,143)$ & $(0,137)$ & $(0,764)$ & $(0,904)$ \\
\hline ASIA(1) & 0,280 & 0,209 & $-0,009$ & 0,108 & $-0,138$ \\
\hline (p value) & $(0,558)$ & $(0,517)$ & $(0,983)$ & $(0,598)$ & $(0,673)$ \\
\hline AUSTRALIA & $-1,475$ & $-0,700$ & $-0,341$ & $-1,813$ & $-0,443$ \\
\hline ( $p$ value) & $(0,764)$ & $(0,876)$ & $(0,650)$ & $(0,288)$ & $(0,396)$ \\
\hline AUSTRALIA(1) & $-1,702$ & $-0,756$ & $-1,882$ & $-3,101$ & $-1,069$ \\
\hline ( $p$ value) & $(0,638)$ & $\left(0,046^{*}\right)$ & $\left(0,036^{*}\right)$ & $(0,007 * *)$ & $(0,065)$ \\
\hline AFRICA & 0,027 & $-0,120$ & $-0,112$ & 0,065 & $-0,017$ \\
\hline ( $p$ value) & $(0,925)$ & $(0,508)$ & $(0,580)$ & $(0,676)$ & $(0,887)$ \\
\hline AFRICA(1) & $-0,026$ & 0,045 & $-0,107$ & $-0,049$ & $-0,365$ \\
\hline (p value) & $(0,903)$ & $(0,862)$ & $(0,727)$ & $(0,725)$ & $(0,188)$ \\
\hline \multicolumn{6}{|l|}{ Results - Variance } \\
\hline \multirow[t]{2}{*}{$\mathrm{C}$} & 1,172 & 1,255 & 1,335 & 0,568 & 1,396 \\
\hline & $(0,001 * *)$ & $(0,000 * *)$ & $(0,005 * *)$ & $\left(0,008^{* *}\right)$ & $\left(0,009^{* *}\right)$ \\
\hline $\operatorname{RESID}(-1)^{\wedge} 2$ & 0,035 & 0,046 & 0,038 & 0,144 & 0,071 \\
\hline $\begin{array}{l}\operatorname{RESID}(-1)^{\wedge} 2 *(\operatorname{RESID}(- \\
1)<0)\end{array}$ & 0,060 & 0,030 & 0,034 & 0,213 & 0,011 \\
\hline GARCH(-1) & 0,577 & 0,588 & 0,577 & 0,581 & 0,588 \\
\hline
\end{tabular}


Table 4, cont.

EUROPE

$\begin{array}{cccccc} & 0,697 & 0,956 & 0,951 & 0,082 & 0,870 \\ \text { (p value) } & (0,057) & (0,007 * *) & (0,466) & (0,879) & \left(0,017^{*}\right)\end{array}$

\begin{tabular}{|c|c|c|c|c|c|}
\hline \multicolumn{6}{|l|}{ Results - Variance } \\
\hline EUROPE(1) & 1,005 & 1,275 & 1,278 & 0,154 & 1,205 \\
\hline ( $p$ value) & $\left(0,016^{*}\right)$ & $(0,004 * *)$ & $(0,223)$ & $(0,793)$ & $(0,001 * *)$ \\
\hline AMERICA & 2,009 & 0,515 & 0,520 & 1,558 & 1,646 \\
\hline ( $p$ value) & $\left(0,019^{*}\right)$ & $(0,482)$ & $(0,757)$ & $(0,056)$ & $\left(0,020^{*}\right)$ \\
\hline AMERICA(1) & 2,635 & 2,669 & 2,677 & 0,304 & 2,263 \\
\hline (p value) & $\left(0,005^{* *}\right)$ & $(0,006 * *)$ & $(0,002 * *)$ & $(0,098)$ & $\left(0,025^{*}\right)$ \\
\hline ASIA & 0,965 & 1,460 & 1,461 & 1,442 & 1,219 \\
\hline (p value) & $(0,088)$ & $\left(0,006^{* *}\right)$ & $(0,713)$ & $\left(0,021^{*}\right)$ & $\left(0,012^{*}\right)$ \\
\hline ASIA(1) & 0,627 & 0,781 & 0,789 & 0,943 & 0,744 \\
\hline (p value) & $(0,494)$ & $(0,134)$ & $(0,442)$ & $(0,007 * *)$ & $(0,201)$ \\
\hline AUSTRALIA & 0,231 & 0,275 & 0,273 & 0,701 & 0,014 \\
\hline (p value) & $(0,988)$ & $(0,884)$ & $(0,553)$ & $(0,605)$ & $(0,998)$ \\
\hline AUSTRALIA(1) & 2,256 & 2,691 & 2,695 & 1,365 & 3,542 \\
\hline (p value) & $(0,921)$ & $(0,214)$ & $(0,012 *)$ & $(0,640)$ & $(0,008 * *)$ \\
\hline AFRICA & 1,106 & 1,158 & 1,156 & 0,605 & 0,117 \\
\hline ( $p$ value) & $(0,001 * *)$ & $(0,004 * *)$ & $\left(0,011^{*}\right)$ & $(0,110)$ & $(0,122)$ \\
\hline AFRICA(1) & 0,737 & 1,007 & 1,004 & 0,415 & 0,138 \\
\hline (p value) & $\left(0,037^{*}\right)$ & $(0,009 * *)$ & $(0,130)$ & $(0,208)$ & $(0,127)$ \\
\hline
\end{tabular}

Note: $* \mathrm{p}<0.05 ; * * \mathrm{p}<0.01$

5.3 Research Question 3 - Tourist Casualties and H/T Stock Indices

The third research question investigated the severity of the event, in terms of both reported tourist fatalities and their volume. The findings, presented in Table 5 unequivocally indicate that incidents with reported tourist fatalities have a significant negative effect in four of the five regional indices (except Asia Pacific) on the day following the event, with the World and Australian indices exhibiting the largest negative impact. In terms of volatility, almost all indices (except Australia) experienced a significant or marginally significant positive impact on the day of the event, with the European index recording the highest effect, both on the day of the event and on the following day.

Table 5: H/T Stock Indices and Tourist Fatalities

\begin{tabular}{lccccc}
\hline & WORLD & ASIA PAC & AUSTRALIA & AMERICA & EUROPE \\
\hline Results - Mean & \multicolumn{5}{c}{} \\
\hline C & 0,030 & 0,010 & 0,035 & 0,026 & 0,030 \\
& $\left(0,027^{*}\right)$ & $(0,175)$ & $(0,051)$ & $(0,086)$ & $\left(0,025^{*}\right)$ \\
FTSE(-1) & 0,086 & $-0,006$ & 0,011 & $-0,011$ & 0,031 \\
(p value) & $\left(0,005^{* *}\right)$ & $(0,885)$ & $(0,454)$ & $(0,514)$ & $\left(0,016^{*}\right)$ \\
Tourist Victims & 0,055 & $-0,061$ & $-0,097$ & $-0,029$ & 0,035 \\
(p value) & $(0,675)$ & $(0,630)$ & $(0,581)$ & $(0,871)$ & 0,819 \\
Tourist Victims $(1)$ & $-0,308$ & $-0,200$ & $-0,309$ & $-0,434$ & $-0,723$ \\
(p value) & $\left(0,007^{* *}\right)$ & $(0,074)$ & $\left(0,005^{* *}\right)$ & $\left(0,019^{*}\right)$ & $\left(0,019^{*}\right)$ \\
\hline Results - Variance & & & & & \\
\hline C & 0,000 & 0,014 & 0,022 & 0,014 & 0,012
\end{tabular}


Table 5 cont.

\begin{tabular}{|c|c|c|c|c|c|}
\hline & $\left(0,003^{* *}\right)$ & $(0,009 * *)$ & $(0,003 * *)$ & $(0,008 * *)$ & $\left(0,005^{* *}\right)$ \\
\hline $\operatorname{RESID}(-1)^{\wedge} 2$ & 0,009 & 0,042 & 0,018 & 0,002 & 0,001 \\
\hline RESID(- & 0,073 & 0,044 & 0,058 & 0,088 & 0,096 \\
\hline \multirow{2}{*}{\multicolumn{6}{|c|}{$\begin{array}{l}1)^{\wedge} 2 *(\operatorname{RESID}(- \\
1)<0)\end{array}$}} \\
\hline & & & & & \\
\hline GARCH(-1) & 0,932 & 0,915 & 0,924 & 0,932 & 0,921 \\
\hline \multicolumn{6}{|l|}{ Results - Variance } \\
\hline Tourist Victims & 0,144 & 0,346 & 0,059 & 0,144 & 1,695 \\
\hline (p value) & $(0,011 *)$ & $(0,005 * *)$ & $(0,079)$ & $\left(0,046^{*}\right)$ & $(0,001 * *)$ \\
\hline Tourist Victims(1) & 0,017 & $-0,163$ & 0,088 & 0,112 & 2,105 \\
\hline ( $p$ value) & $(0,832)$ & $(0,180)$ & $(0,737)$ & $(0,059)$ & $(0,002 * *)$ \\
\hline
\end{tabular}

Note: $* \mathrm{p}<0.05 ; * * \mathrm{p}<0.01$

The second part of the third question examined whether the number of tourist fatalities, a direct reflection of an incident's severity, impacted upon the H/T stock indices. For the empirical analysis, the events were grouped into three distinctive categories, namely events with less than 10 fatalities (VICT10), events with 10 to less than 100 fatalities (VICT_L100), and events with more than 100 casualties (VICT_G100). The findings (see Table 6) suggested that the higher the number of tourist fatalities, the higher the negative impact of these incidents on hospitality and tourism stock indices, especially on the following day. The World, Asia Pacific, and Australian stock indices exhibited a significant negative effect on the day of an event, which caused more than 100 tourist casualties. On the following day, almost all three categories negatively impacted the indices with some minor exceptions (for example, events with less than 10 casualties have an insignificant effect on the Asia Pacific, Australian, American and European indices).

It is important to note that, on average, the impact of incidents with more than 10 and less than 100 victims was more than double compared with the corresponding impact of incidents with less than 10 victims. Interestingly, the impact of incidents with more than 100 victims was more than three times higher than the corresponding impact of incidents with more than 10 and less than 100 victims. Finally, in terms of volatility, all five stock indices experienced significant positive effects, both on the day of the event, and on the following day, with the Asia Pacific and European indices being more vulnerable to such events.

Table 6: Severity (number of tourist casualties) and H/T Stock Indic

\section{WORLD ASIA PAC AUSTRALI AMERIC EUROPE}

A

A

\begin{tabular}{lccccc}
\hline Results - Mean & \multicolumn{5}{c}{} \\
\hline C & 0,032 & $-0,004$ & 0,045 & 0,033 & 0,013 \\
& $\left(0,027^{*}\right)$ & $(0,979)$ & $\left(0,021^{*}\right)$ & $(0,071)$ & $(0,558)$ \\
FTSE(-1) & 0,085 & $-0,004$ & 0,004 & $-0,019$ & 0,040 \\
(p value) & $\left(0,001^{* *}\right)$ & $(0,847)$ & $(0,517)$ & $(0,492)$ & $\left(0,038^{*}\right)$ \\
VICT10 & 0,031 & $-0,304$ & $-0,127$ & $-0,056$ & 0,088 \\
(p value) & $(0,900)$ & $\left(0,028^{*}\right)$ & $(0,059)$ & $(0,776)$ & $(0,781)$ \\
VICT_L100 & 0,023 & 0,000 & $-0,206$ & $-0,051$ & $-0,031$ \\
(p value) & $(0,836)$ & $(0,988)$ & $\left(0,026^{*}\right)$ & $(0,802)$ & $(0,798)$ \\
VICT_G100 & $-0,195$ & $-0,539$ & $-0,247$ & $-0,089$ & 0,015 \\
(p value) & $\left(0,035^{*}\right)$ & $\left.(0,00)^{* *}\right)$ & $\left(0,049^{*}\right)$ & $(0,690)$ & $(0,969)$ \\
VICT10(1) & $-0,122$ & $-0,111$ & 0,001 & $-0,353$ & $-0,173$
\end{tabular}


Table 6, cont.

\begin{tabular}{|c|c|c|c|c|c|}
\hline (p value) & $\left(0,026^{*}\right)$ & $(0,068)$ & $(0,966)$ & $(0,102)$ & $0,065)$ \\
\hline VICT_L100(1) & $-0,208$ & $-0,248$ & $-0,205$ & $-0,451$ & $-0,416$ \\
\hline ( $p$ value) & $(0,099)$ & $\left(0,019^{*}\right)$ & $\left(0,030^{*}\right)$ & $(0,083)$ & $(0,002 * *)$ \\
\hline VICT_G100(1) & $-0,646$ & $-0,512$ & $-0,634$ & $-0,709$ & $-0,465$ \\
\hline ( $p$ value) & $(0,003 * *)$ & $(0,020 *)$ & $(0,013 *)$ & $(0,058)$ & $(0,001 * *)$ \\
\hline \multicolumn{6}{|l|}{ Results - Variance } \\
\hline \multirow[t]{2}{*}{$\mathrm{C}$} & 0,005 & 1,150 & 0,020 & 0,023 & 0,866 \\
\hline & $(0,009 * *)$ & $(0,009 * *)$ & $(0,005 * *)$ & $(0,002 * *)$ & $(0,004 * *)$ \\
\hline $\operatorname{RESID}(-1)^{\wedge} 2$ & 0,008 & 0,052 & 0,019 & 0,019 & 0,049 \\
\hline $\begin{array}{l}\operatorname{RESID}(-1)^{\wedge} 2 *(\operatorname{RESID}(- \\
1)<0)\end{array}$ & 0,085 & 0,045 & 0,051 & 0,099 & 0,119 \\
\hline GARCH(-1) & 0,942 & 0,572 & 0,921 & 0,934 & 0,574 \\
\hline VICT10 & 0,287 & 0,636 & 0,554 & 0,182 & 1,159 \\
\hline ( $p$ value) & $(0,005 * *)$ & $(0,034 *)$ & $\left(0,016^{*}\right)$ & $(0,028 *)$ & $(0,042 *)$ \\
\hline VICT_L100 & 0,279 & 0,807 & 0,070 & 0,531 & 0,639 \\
\hline (p value) & $(0,024 *)$ & $(0,004 * *)$ & $(0,841)$ & $(0,014 *)$ & $\left(0,010^{*}\right)$ \\
\hline VICT_G100 & 0,206 & 1,350 & 0,791 & 0,583 & 1,279 \\
\hline (p value) & $(0,066)$ & $(0,005 * *)$ & $(0,023 *)$ & $(0,051)$ & $\left(0,021^{*}\right)$ \\
\hline VICT10(1) & 0,244 & 1,294 & 0,310 & 0,139 & 2,235 \\
\hline ( $p$ value) & $(0,009 * *)$ & $(0,004 * *)$ & $\left(0,036^{*}\right)$ & $(0,048 *)$ & $(0,005 * *)$ \\
\hline VICT_L100(1) & 0,081 & 0,960 & 0,264 & 0,176 & 1,265 \\
\hline (p value) & $(0,507)$ & $(0,009 * *)$ & $(0,095)$ & $(0,047 *)$ & $(0,008 * *)$ \\
\hline VICT_G100(1) & 0,381 & 0,688 & 0,725 & 0,873 & 0,643 \\
\hline ( $p$ value) & $(0,039 *)$ & $(0,003 * *)$ & $\left(0,026^{*}\right)$ & $(0,029 *)$ & $(0,008 * *)$ \\
\hline
\end{tabular}

Note: $* \mathrm{p}<0.05 ; * * \mathrm{p}<0.01$

\subsection{Research Question 4: Attacks on Tourism Infrastructure / Superstructure and H/T Stock Indices}

Historically, the tourism industry surfaced as a convenient target for terrorism groups wishing to maximize their radical ideological agendas on the world stage. The industry's infrastructure/superstructure (such as airports, hotels, restaurants, and leisure venues) have been ideal targets, nevertheless, the actual impact of such attacks on H/T stock indices has received limited scholarly attention. The findings (see Table 7) suggest that attacks on tourism infrastructure cause a significant negative impact on most indices (except for the Asia Pacific), mostly on the day following the event. The European index seems the most susceptible to such attacks, especially on the next day $(-0,581 ; p=0,001)$, a trend that is also evident with regard to volatility. Such attacks caused a significant positive impact on the corresponding uncertainty (or risk) of these markets in all regions, again with European and Asia Pacific indices recording the highest volatility increases.

Table 7: Attacks on Tourism Infrastructure H/T Stock Indices

\begin{tabular}{lccccc}
\hline & WORL & ASIA & AUSTRALI & AMERIC & EUROP \\
& D & PAC & A & A & E \\
\hline Results - Mean & & & & & \\
\hline C & 0,033 & 0,009 & 0,030 & 0,044 & 0,037 \\
& $\left(0,022^{*}\right)$ & $(0,748)$ & $\left(0,044^{*}\right)$ & $(0,060)$ & $\left(0,007^{* *}\right)$ \\
FTSE(-1) & 0,089 & 0,001 & 0,012 & $-0,016$ & 0,034
\end{tabular}


Table 7, cont.

( $\mathrm{p}$ value)

$$
(0,010 *) \quad(0,909)
$$

$(0,464)$

$(0,519) \quad(0,021 *)$

Infrastructure

$-0,049 \quad-0,212$

$-0,111$

$-0,183$

$-0,005$

( $\mathrm{p}$ value)

\begin{tabular}{|c|c|c|c|c|c|}
\hline & $(0,648)$ & $(0,002 * *)$ & $(0,363)$ & $(0,163)$ & $(0,997)$ \\
\hline Infrastructure(1) & $-0,228$ & 0,005 & $-0,255$ & $-0,316$ & $-0,581$ \\
\hline (p value) & $\left(0,013^{*}\right)$ & $(0,922)$ & $(0,087)$ & $\left(0,041^{*}\right)$ & $\left(0,001^{* *}\right)$ \\
\hline \multicolumn{6}{|l|}{ Results - Variance } \\
\hline \multirow[t]{3}{*}{$\mathrm{C}$} & 0,006 & 1,062 & 0,031 & 0,009 & 0,013 \\
\hline & $(0,000 * *$ & $\left(0,003^{* *}\right)$ & $\left(0,010^{*}\right)$ & $(0,008 * *)$ & $(0,005 * *)$ \\
\hline & ) & & & & \\
\hline $\operatorname{RESID}(-1)^{\wedge} 2$ & 0,019 & 0,053 & 0,030 & 0,015 & 0,007 \\
\hline \multicolumn{6}{|l|}{ Results - Variance } \\
\hline $\operatorname{RESID}(-1)^{\wedge} 2 *(\operatorname{RESID}(-1)<0)$ & 0,082 & 0,051 & 0,061 & 0,101 & 0,101 \\
\hline GARCH(-1) & 0,928 & 0,556 & 0,932 & 0,925 & 0,926 \\
\hline Infrastructure & 0,167 & 1,063 & 0,155 & 0,234 & 1,088 \\
\hline ( $p$ value) & $(0,023 *)$ & $\left(0,006^{* *}\right)$ & $(0,042 *)$ & $(0,013 *)$ & $(0,003 * *)$ \\
\hline Infrastructure(1) & $-0,010$ & 0,871 & 0,081 & 0,051 & 1,434 \\
\hline ( $p$ value) & $(0,926)$ & $(0,002 * *)$ & $(0,080)$ & $(0,790)$ & $(0,002 * *)$ \\
\hline
\end{tabular}

Note: $* \mathrm{p}<0.05 ; * \mathrm{p}<0.01$

\subsection{Research Question 5: Type of Attack and H/T Stock Indices}

The study's fifth research question explored whether the type of attack influences H/T stock indices. For this purpose, attacks were classified into two distinct categories according to the perpetrators' fate, namely killed or apprehended during the attack (such as suicide bombers), and perpetrators who were later apprehended or were still at large. The results, shown in Table 8, indicate that the type of attack was relevant only for the European index with a significant negative impact on the following day of the event $(-0,380 ; p=0,005)$. It is apparent that the type of attack has no direct impact on the other regions' indices, whereas a significant positive impact on stock market uncertainty is revealed in the World (on the day of the attack), Asia Pacific and European indices, again with the latter recording the highest increase for both days.

Table 8: Type of Attack and H/T Stock Indices

\section{WORLD ASIA AUSTRALIA AMERICA EUROPE \\ PAC}

\begin{tabular}{lccccc}
\hline Results - Mean & \multicolumn{5}{c}{} \\
\hline C & 0,034 & 0,027 & 0,044 & 0,029 & 0,024 \\
& $\left(0,040^{*}\right)$ & $(0,141)$ & $\left(0,042^{*}\right)$ & $(0,101)$ & $(0,653)$ \\
FTSE(-1) & 0,087 & 0,000 & 0,004 & $-0,017$ & 0,053 \\
(p value) & $\left(0,002^{* *}\right)$ & $(0,849)$ & $(0,473)$ & $(0,503)$ & $\left(0,040^{*}\right)$ \\
Attack & $-0,036$ & $-0,131$ & $-0,196$ & $-0,152$ & $-0,114$ \\
(p value) & $(0,710)$ & $(0,216)$ & $(0,127)$ & $(0,323)$ & $(0,413)$ \\
Attack(1) & $-0,087$ & $-0,094$ & $-0,190$ & $-0,137$ & $-0,380$ \\
(p value) & $(0,398)$ & $(0,288)$ & $(0,144)$ & $(0,278)$ & $\left(0,005^{* *}\right)$ \\
\hline Results - Variance & & & & \\
\hline C & 0,002 & 0,025 & 0,025 & 0,022 & 1,401 \\
& $\left(0,000^{* *}\right)$ & $\left(0,001^{* *}\right)$ & $\left(0,008^{* *}\right)$ & $\left(0,004^{* *}\right)$ & $\left(0,007^{* *}\right)$
\end{tabular}


Table 8, cont.

\begin{tabular}{lccccc}
$\operatorname{RESID}(-1)^{\wedge} 2$ & 0,014 & 0,036 & 0,036 & 0,012 & 0,066 \\
$\operatorname{RESID}(-1)^{\wedge} 2^{*}(\operatorname{RESID}(-$ & 0,072 & 0,041 & 0,052 & 0,086 & 0,032 \\
$\begin{array}{l}1)<0) \\
\text { GARCH}(-1)\end{array}$ & 0,936 & 0,917 & 0,937 & 0,924 & 0,594 \\
Attack & 0,240 & 0,291 & 0,137 & 0,220 & 0,769 \\
& & & & & ( \\
(p value) & $\left(0,008^{* *}\right)$ & $\left(0,008^{* *}\right)$ & $0,543)$ & $(0,196)$ & $\left.0,000^{* *}\right)$ \\
& 0,115 & 0,231 & $-0,025$ & $-0,007$ & 1,703 \\
Attack $(1)$ & $(0,134)$ & $\left(0,003^{* *}\right)$ & $(0,916)$ & $(0,977)$ & $(0,002 * *)$ \\
\hline p value) & & & & &
\end{tabular}

Note: $* \mathrm{p}<0.05 ; * * \mathrm{p}<0.01$

\subsection{Research Question 6: Affiliation of the Attackers and H/T Stock Indices}

Recent literature (Aslam \& Kang, 2015) suggests that the specificities of a terrorist attack influence its overall impact on financial markets. In order to further explore this argument, the affiliation of the attackers, classified into known terrorist organizations (such as Al-Qaeda) and Lone Wolves, was examined. A Lone Wolf is defined as an individual who commits an act of violence alone without any logistical support from an organized group, despite the fact that he or she may espouse the ideology of a radical group or movement (for example, the 2015 Copenhagen Shootings). The findings, presented in Table 9, suggest that the attackers' affiliation is not relevant to any of the five indices under consideration as no significant changes are recorded. In contrast, when investigating a market's volatility, significant positive increases are revealed for both the Asia Pacific and European indices, both on the day of the event and on the next day.

Table 9: Affiliation of Attackers and H/T Stock Indices

\begin{tabular}{|c|c|c|c|c|c|}
\hline & WORLD & ASIA PAC & $\begin{array}{c}\text { AUSTRALI } \\
\text { A } \\
\end{array}$ & $\begin{array}{c}\text { AMERIC } \\
\text { A }\end{array}$ & EUROPE \\
\hline \multicolumn{6}{|l|}{ Results - Mean } \\
\hline $\mathrm{C}$ & $\begin{array}{c}0,025 \\
(0,078)\end{array}$ & $\begin{array}{c}0,010 \\
(0,920)\end{array}$ & $\begin{array}{c}0,038 \\
(0,100)\end{array}$ & $\begin{array}{c}0,019 \\
(0,173)\end{array}$ & $\begin{array}{c}0,032 \\
\left(0,026^{*}\right)\end{array}$ \\
\hline $\begin{array}{l}\text { FTSE }(-1) \\
\text { (p value) }\end{array}$ & $\begin{array}{c}0,097 \\
(0,008 * * \\
)\end{array}$ & $\begin{array}{c}-0,023 \\
(0,007 * *)\end{array}$ & $\begin{array}{c}0,008 \\
(0,449)\end{array}$ & $\begin{array}{l}-0,016 \\
(0,558)\end{array}$ & $\begin{array}{c}0,041 \\
\left(0,020^{*}\right)\end{array}$ \\
\hline $\begin{array}{l}\text { Affiliation } \\
\text { ( } \mathrm{p} \text { value) } \\
\text { Affiliation(1) } \\
\text { (p value) }\end{array}$ & $\begin{array}{c}0,165 \\
(0,285) \\
-0,091 \\
(0,488)\end{array}$ & $\begin{array}{c}-0,116 \\
(0,057) \\
-0,098 \\
(0,139)\end{array}$ & $\begin{array}{c}0,072 \\
(0,663) \\
0,007 \\
(0,986)\end{array}$ & $\begin{array}{l}-0,151 \\
(0,439) \\
-0,194 \\
(0,302) \\
\end{array}$ & $\begin{array}{c}0,139 \\
(0,367) \\
-0,535 \\
(0,082) \\
\end{array}$ \\
\hline \multicolumn{6}{|l|}{ Results - Variance } \\
\hline 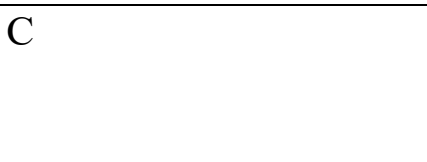 & $\begin{array}{c}0,001 \\
(0,002 * * \\
)\end{array}$ & $\begin{array}{c}0,758 \\
\left(0,006^{* *}\right)\end{array}$ & $\begin{array}{c}0,021 \\
\left(0,001^{* *}\right)\end{array}$ & $\begin{array}{c}0,019 \\
(0,000 * *)\end{array}$ & $\begin{array}{c}0,024 \\
(0,009 * *)\end{array}$ \\
\hline $\operatorname{RESID}(-1)^{\wedge} 2$ & 0,012 & 0,094 & 0,031 & 0,001 & 0,017 \\
\hline $\begin{array}{l}\operatorname{RESID}(-1)^{\wedge} 2 *(\operatorname{RESID}(- \\
1)<0)\end{array}$ & 0,074 & 0,086 & 0,054 & 0,087 & 0,103 \\
\hline GARCH(-1) & 0,947 & 0,349 & 0,935 & 0,942 & 0,914 \\
\hline $\begin{array}{l}\text { Affiliation } \\
\text { (p value) }\end{array}$ & $\begin{array}{c}0,101 \\
(0,394)\end{array}$ & $\begin{array}{c}0,618 \\
(0,007 * *)\end{array}$ & $\begin{array}{c}0,339 \\
(0,208)\end{array}$ & $\begin{array}{c}0,096 \\
(0,739)\end{array}$ & $\begin{array}{c}1,376 \\
\left(0,005^{* *}\right)\end{array}$ \\
\hline $\begin{array}{l}\text { Affiliation( } 1 \text { ) } \\
\text { (p value) }\end{array}$ & $\begin{array}{c}0,010 \\
(0,900)\end{array}$ & $\begin{array}{c}0,853 \\
\left(0,004^{* *}\right)\end{array}$ & $\begin{array}{c}0,252 \\
(0,351)\end{array}$ & $\begin{array}{c}0,128 \\
(0,627)\end{array}$ & $\begin{array}{c}1,618 \\
(0,003 * *)\end{array}$ \\
\hline
\end{tabular}

Note: $* \mathrm{p}<0.05 ; * \mathrm{p}<0.01$ 


\subsection{Research Question 7: Media Exposure and H/T Stock Indices}

The final research question examined whether post-event media coverage impacts on H/T stock indices, both in terms of returns and volatility. Each event's media coverage and exposure was classified as either High/Global or Low/Regional, based on information received from various internet sources. The subjective nature of this exercise is acknowledged, therefore, the results are presented for purely indicative purposes. The findings (see Table 10) indicated that media exposure had a significant negative impact on the four indices (except Asia Pacific), mostly on the day following the incident. With regard to market uncertainty (volatility), all five indices experienced a significant increase, mostly on the day following the event, with the European index seen as the most susceptible to such an effect.

Table 10: Media Exposure and H/T Stock Indices

\begin{tabular}{|c|c|c|c|c|c|}
\hline & WORLD & $\begin{array}{l}\text { ASIA } \\
\text { PAC }\end{array}$ & $\begin{array}{c}\text { AUSTRALI } \\
\text { A }\end{array}$ & AMERICA & EUROPE \\
\hline \multicolumn{6}{|l|}{ Results - Mean } \\
\hline \multirow[t]{2}{*}{$\mathrm{C}$} & 0,029 & 0,025 & 0,040 & 0,033 & 0,043 \\
\hline & $\left(0,031^{*}\right)$ & $(0,145)$ & $(0,055)$ & $(0,077)$ & $\left(0,026^{*}\right)$ \\
\hline $\operatorname{FTSE}(-1)$ & 0,089 & 0,005 & 0,011 & $-0,008$ & 0,043 \\
\hline ( $p$ value) & $(0,005 * *)$ & $(0,777)$ & $(0,489)$ & $(0,543)$ & $(0,029 *)$ \\
\hline Media & $-0,073$ & $-0,231$ & $-0,179$ & $-0,149$ & $-0,207$ \\
\hline ( $p$ value) & $(0,561)$ & $(0,064)$ & $\left(0,025^{*}\right)$ & $\left(0,046^{*}\right)$ & $\left(0,025^{*}\right)$ \\
\hline Media(1) & $-0,373$ & $-0,162$ & $-0,323$ & $-0,488$ & $-0,870$ \\
\hline ( $p$ value) & $(0,000 * *)$ & $(0,176)$ & $\left(0,017^{*}\right)$ & $\left(0,021^{*}\right)$ & $\left(0,014^{*}\right)$ \\
\hline \multicolumn{6}{|l|}{ Results - Variance } \\
\hline \multirow[t]{2}{*}{$\mathrm{C}$} & 0,016 & 0,018 & 0,013 & 0,020 & 0,011 \\
\hline & $\left(0,008^{* *}\right)$ & $(0,003 * *)$ & $(0,002 * *)$ & $(0,001 * *)$ & $\left(0,005^{* *}\right)$ \\
\hline $\operatorname{RESID}(-1)^{\wedge} 2$ & 0,019 & 0,035 & 0,025 & 0,000 & 0,013 \\
\hline $\begin{array}{l}\operatorname{RESID}(-1)^{\wedge} 2^{*}(\operatorname{RESID}(- \\
1)<0)\end{array}$ & 0,082 & 0,046 & 0,063 & 0,087 & 0,109 \\
\hline GARCH(-1) & 0,936 & 0,909 & 0,926 & 0,928 & 0,913 \\
\hline Media & 0,026 & 0,351 & 0,234 & $-0,059$ & 1,165 \\
\hline ( $p$ value) & $(0,086)$ & $(0,007 * *)$ & $\left(0,046^{*}\right)$ & $(0,892)$ & $(0,002 * *)$ \\
\hline Media(1) & 0,207 & 0,114 & 0,484 & 0,488 & 1,562 \\
\hline ( $p$ value) & $\left(0,026^{*}\right)$ & $\left(0,042^{*}\right)$ & $\left(0,025^{*}\right)$ & $\left(0,014^{*}\right)$ & $\left(0,006^{* *}\right)$ \\
\hline
\end{tabular}

Note: $* \mathrm{p}<0.05 ; * * \mathrm{p}<0.01$

\subsection{Half-life Volatility Shocks}

In an attempt to further investigate the volatility shock persistence for each of the seven research questions, the half-life method, defined as $\ln (0.5) / \ln \left(a^{2}+b^{2}\right)$, which measures the period of time (or number of days) it takes for the shock's impact to decrease by one-half, was used. The particular technique has been used by numerous scholars (see, for example, Lamoureux \& Lastrapes, 1990) for dissecting the behavior of volatility after a particular incident. The findings, presented in Table 11, suggest that volatility shocks, similar to returns, appear to be largely transitory in nature, with halflife estimates being around 4 to 5 days for most events. Noteworthy differences do exist, both between the five indices under consideration, particularly regarding the Asia Pacific index, and according to incidents' characteristics. 
Table 11: Half-life of Volatility Shocks Persistence

\begin{tabular}{|l|c|c|c|c|c|c|c|c|c|c|c|}
\hline $\begin{array}{l}\text { Regio } \\
\mathbf{n}\end{array}$ & $\begin{array}{c}\text { W/O } \\
\text { dummi } \\
\text { es }\end{array}$ & $\begin{array}{c}\text { RQ1a } \\
\text { (Terror } \\
\text { ism) }\end{array}$ & $\begin{array}{c}\text { RQ1b } \\
\text { ('Acts } \\
\text { of } \\
\text { God') }\end{array}$ & $\begin{array}{c}\text { RQ1c } \\
\text { (War } \\
\text { Conflic } \\
\text { ts) }\end{array}$ & $\begin{array}{c}\text { RQ2 } \\
\text { (Geograp } \\
\text { h. } \\
\text { Location) }\end{array}$ & $\begin{array}{c}\text { RQ3_fatal } \\
\text { (Tourist } \\
\text { Fatalities) }\end{array}$ & $\begin{array}{c}\text { RQ3_tour_ } \\
\text { vic } \\
\text { (Number of } \\
\text { Victims) }\end{array}$ & $\begin{array}{c}\text { RQ4 } \\
\text { (Infrastr./ } \\
\text { Superstr.) }\end{array}$ & $\begin{array}{c}\text { RQ5 } \\
\text { (Type of } \\
\text { Attack) }\end{array}$ & $\begin{array}{c}\text { RQ6 } \\
\text { (Affilia } \\
\text { tion) }\end{array}$ & $\begin{array}{c}\text { RQ7 } \\
\text { (Media } \\
\text { Covera } \\
\text { ge) }\end{array}$ \\
\hline $\begin{array}{l}\text { WORL } \\
\text { D }\end{array}$ & 95.139 & 5.513 & 6.098 & 0.728 & 0.632 & 5.755 & 4.890 & 4.680 & 5.219 & 6.382 & 5.249 \\
\hline $\begin{array}{l}\text { ASIA } \\
\text { PAC }\end{array}$ & $\begin{array}{c}152.82 \\
6\end{array}$ & 4.503 & 4.325 & 4.118 & 0.656 & 0.625 & 3.934 & 0.596 & 4.023 & 0.340 & 3.680 \\
\hline $\begin{array}{l}\text { AUST } \\
\text { RALI } \\
\text { A }\end{array}$ & 45.331 & 4.842 & 0.612 & 0.462 & 0.632 & 4.228 & 4.424 & 4.946 & 5.388 & 5.241 & 4.513 \\
\hline $\begin{array}{l}\text { AMER } \\
\text { ICA }\end{array}$ & 71.438 & 5.716 & 5.019 & 1.267 & 0.676 & 5.058 & 4.907 & 4.475 & 4.419 & 5.835 & 4.656 \\
\hline $\begin{array}{l}\text { EURO } \\
\text { PE }\end{array}$ & 31.226 & 0.662 & 3.844 & 3.777 & 0.661 & 0.628 & 4.185 & 4.537 & 0.673 & 3.847 & 3.834 \\
\hline
\end{tabular}

\section{Discussion and Implications}

Aligned with existing literature (Brounrn \& Derwall, 2010; Chesney et al., 2011; Drakos, 2010), the findings suggest that non-macro incidents caused a short-term transitory effect on H/T stock indices, with recovery occurring within two to three days. As revealed, differences exist according to the incident type (Terrorist attacks, 'Act of God', War conflicts), with terrorist attacks recording statistically the most significant drops, especially on the day following the event, and 'Acts of God' exhibiting drops on the day of the incident. In contrast, Wars had an insignificant effect on four of the five study-specific indices (except for the World index).

The specificities of each event were explored with the use of a number of variables, such as geographic location, severity, specific target, type of the attack, perpetrators' affiliation, and postevent media exposure and coverage. The literature (see Aslam \& Kang, 2015; Chesney, Reshetarb, \& Karamana, 2011; Essaddam \& Karagianis, 2014) suggests that the characteristics of each incident influence its overall impact on both stock market returns and volatility. Thus, an enhanced understanding of these parameter estimates would most certainly assist stakeholders in predicting the financial consequences of an incident, as well as instigating recovery initiatives. The findings suggest that only incidents occurring in the USA have a global impact on almost all indices, whereas other incidents mostly affect the particular regional stock markets. In terms of severity (referred to in some studies as the intensity of the incident), the findings indicate that events resulting in tourist casualties have a significant negative impact on all five indices, whereas this impact was exponentially higher for incidents with more than 100 fatalities; a notion that is also supported by Aslam and Kang (2015). Incidents involving attacks on tourism infrastructure and superstructure had a significant negative effect on the World, European and American indices, mostly on the day following the event. This tends to support Brounrn and Derwall's (2010) argument that industries directly affected or involved in the attack experience considerably stronger effects. The type of terrorist attack was also investigated with research (for example, Eldor \& Melnick, 2004; Kollias et al., 2011) suggesting a number of different scenarios. For instance, Kollias et al. (2011) argued that stock behavior and the subsequent recovery period may be affected by the type of the attack, with London (2004) presented as an example of a single day recovery due to the incident's nature (suicide bombings) compared with the Madrid attacks in 2005 (where the perpetrators were apprehended a few days later). This study's findings suggest that the European index is significantly more susceptible to the type of attack, both in terms of returns and volatility.

The affiliation of the perpetrators was investigated, with the reasoning being that attacks conducted by known terrorist groups will have a more lasting impact compared with Lone Wolf incidents. The findings fail to confirm this argument as no significant changes were recorded in any of the five indices. In contrast, market uncertainty is significantly higher for both the Asia Pacific and the European indices, thereby suggesting that both regions are more vulnerable if the perpetrators' affiliation is a well-known terrorist group. Finally, and as expected, the extensiveness of media coverage, a pragmatic reality when incidents cause international tourists fatalities, influences the event's overall impact, both on returns and volatility. 
With minor exceptions, overall volatility exhibits similar reactions to returns. The half-life volatility shock persistence estimates revealed some noteworthy differences, especially between the Asia Pacific and the other indices. Nevertheless, in comparison with the existing literature, this paper produced no evidence to support claims that, following a particular incident, volatility will significantly increase for up to 15 days (as suggested by Essaddam \& Karagianis, 2014), or that 'Acts of God' increase uncertainty more, compared with other incidents, due to the observed post-event negative impact (as suggested by Chesney et al., 2011). It would be prudent to encourage further empirical investigation in volatility persistence following such incidents.

\subsection{Implications}

The capability of financial institutions to predict both the likelihood and probable consequences of non-macro incidents is crucial in today's business environment. With the use of an appropriate econometric methodology, this paper aimed to enhance our conceptual knowledge as to how the characteristics of each incident (such as type, location, severity, and affiliation) affect stock market reactions and behavior, particularly those of the five study-specific $\mathrm{H} / \mathrm{T}$ stock indices. Despite the fact that, overall, our findings exhibited similar outcomes with several previous studies that investigated pertinent topics in generic business indices (such as Brounrn \& Derwall, 2010; Nikkinen \& Vähämaa, 2010), noteworthy implications are of interest to hospitality and tourism stakeholders, including investors, local authorities, financial institutions, tourism-service providers (such as tour operators), and industry operators.

The paper indicated that the negative impact of non-macro incidents on hospitality-specific indices (returns) is short lived and does not last more than 2-3 days. With the exception of cataclysmic events, such as the September 11th, 2001 attacks or the 2004 Indian Ocean Earthquake and Tsunami, which had an unprecedented psychological impact on financial markets caused by the nature, magnitude and severity of the incident (Brounrn \& Derwall, 2010; Drakos, 2004), financial markets appeared to be efficient and resilient in absorbing the initial shock of such incidents (Johnston \& Nedelescu, 2006). It is apparent that recent past experiences have 'forced' the industry to create its own 'antibodies' in order to self-protect and immune itself to such eventualities. A contributing factor was the fact that, following the aftermath of the September 11th, 2001 attacks in the USA, the majority of financial markets, especially those operating in developed countries, undertook drastic measures in enhancing their contingency plans and crisis management responses in order to mitigate their exposure and vulnerability to such eventualities (Kollias et al., 2011).

It is, therefore, prudent to suggest that the investors' negative exposure from such events is minimal. Nevertheless, market uncertainty (volatility) is still a topic worthy of further investigation. Note that, for investors, high market volatility will severely limit the well-established benefits of portfolio diversification, an ideal investment practice for the global tourism industry, especially at the international level (Lee, Wu, \& Wang, 2007; McAleer, 2015). Moreover, this short-term transient effect seems to be inconsistent with some recent calls (see, for example, Chesney et al., 2011) to avoid investing in hospitality and tourism related stocks due to terrorist-related incidents.

The profile of the incident and its geographic location may assist financial institutions in better quantifying their risk exposure. For tourism, incidents occurring in developed countries (mostly in Europe and the USA), causing tourist fatalities, involving the industry's infrastructure and superstructure and, logically, generating extensive media coverage, thereby influencing individuals' psycho-social state, require immediate attention as they can have a significant impact on markets. In contrast, terrorist incidents occurring in Africa, a geostrategic region with a 'rich' history of political instability, and with numerous 'active' conflict zones (such as Somalia, Yemen, Libya, Kenya, and Tunisia) have an insignificant effect on the study-specific indices. The findings echo the argument of Essaddam and Karagianis (2014) that the characteristics of the geographic location in which the incident occurred impact on stock markets.

At the destination level, the findings have implications for tourism policymakers striving to mitigate the negative impact from such events. Depending on the type, impact, severity, and location of the incident, stakeholders may undertake specific measures that minimize their risk exposure and safeguard the sustainability of their industry. The development of pre- and post-event strategies, and 
the adoption of specific measures by the destination's highest institutions, both political and financial (such as Government, Central Bank, Local Authorities, and Regional Stock Markets), will most definitely enhance the confidence and trust of current and potential investors and safeguard the industry's financial interests.

Such targeted measures may include, among others, mitigation tactics and actions (post event crisis management and communication), modifications and reconfigurations on existing regulatory financial frameworks (revision of monetary and fiscal policies), precautionary/preventive actions (actions to eliminate terrorist finance and related money laundering), increased scrutiny to suspicious financial transactions, enhance international cooperation and information sharing (cooperation between European Union countries under the auspices of the European Central Bank), and inter-andcross departmental cooperation, both domestic and international (cooperation between financial institutions and security/law enforcement agencies). Furthermore, hospitality organizations may undertake strategic market diversification initiatives, which may encourage, for example, the promotion of domestic tourism at destinations that are overly dependent on international markets, thereby minimizing the susceptibility to such events.

One aspect that cannot be ignored is the long-term indirect effects of such incidents on the tourism industry. Despite the transient effect on stock markets, such events can significantly increase the industry's cost of doing business. Frey, Luechinger and Stutzer (2007) introduced the indirect effects (for example, the cost imposed on the local population) of such incidents; effects that cannot be reflected in the next day's stock market prices and returns. Moreover, systemic side effects, which may take time to materialize as they depend heavily on each country's distinctive economic situation and national risk, present an intriguing topic worthy of further investigation. Another possible research endeavor is the investigation as to whether such incidents have a more direct effect on hospitality establishments' sales and profitability than they do on stock performance. This thematic area contains numerous topics that are of interest to industry stakeholders, and are worthy of further investigation.

\section{References}

[1] Arin, K.P., Ciferri, D., \& Spagnolo, N. (2008). The price of terror: The effects of terrorism on stock market returns and volatility. Economics Letters, 101(3), 164-167.

[2] Aslam, F., \& Kang, H.G. (2015). How different terrorist attacks affect stock markets. Defence and Peace Economics, 26(6), 634-648.

[3] Avraham, E. (2013). Crisis communication, image restoration, and battling stereotypes of terror and wars: Media strategies for attracting tourism to Middle Eastern countries. American Behavioral Scientist, 57(9), 1350-1367.

[4] Barrows, C.W., \& Naka, A. (1994). Use of macroeconomic variables to evaluate selected hospitality stock returns in the U.S. International Journal of Hospitality Management, 13(2), 119-128.

[5] Blake, A., \& Sinclair, T. (2003). Tourism crisis management: US response to September 11. Annals of Tourism Research, 30(4), 813-832.

[6] Brent Ritchie, J.R., Molinar, C.M.A., \& Frechtling, D.C. (2010). Impacts of the World recession and economic crisis on tourism: North America. Journal of Travel Research, 49(1), 5-15.

[7] Brounrn, D., \& Derwall, J. (2010). The impact of terrorist attacks on international stock markets. European Financial Management, 16(4), 585-598.

[8] Cadavez, C. (2016). Tourism and terrorism: Protecting paradise. Aviation Security International, 22 (1), 28-30. Retrieved from, http://comum.rcaap.pt/bitstream/10400.26/11930/1/2016.01.002_.pdf

[9] Chan, F., Lim, C., \& McAleer, M. (2005). Modelling multivariate international tourism demand and volatility. Tourism Management, 26, 459-471. 
[10]Charles, A., \& Darne, O. (2006). Shocks and the September 11th terrorist attacks on international stock markets. Economic Modelling, 23 (4), 683-698.

[11] Chen, A.H., \& Siems, T.F. (2004). The effects of terrorism on global capital markets. European Journal of Political Economy, 20(2), 349-366.

[12] Chen, M.H. (2007). Macro and non-macro explanatory factors of Chinese hotel stock returns. International Journal of Hospitality Management, 26(4), 991-1004.

[13] Chen, M.H. (2011). The response of hotel performance to international tourism development and crisis events. International Journal of Hospitality Management, 30(1), 200-212.

[14] Chen, M.H., Jang, S.C., \& Kim, W.G. (2007). The impact of the SARS outbreak on Taiwanese hotel stock performance: an event-study approach. International Journal of Hospitality Management, 26(1), 200-212.

[15] Chen, M.H., Kim, W.G., \& Kim, H.J. (2005). The impact of macroeconomic and nonmacroeconomic forces on hotel stock returns. International Journal of Hospitality Management, 24(2), 243-258.

[16] Chesney, M., Reshetarb, G., \& Karamana, M. (2011). The impact of terrorism on financial markets: an empirical study. Journal of Banking and Finance, 35(2), 253-267.

[17] Drakos, K. (2004). Terrorism-induced structural shifts in financial risk: Airline stocks in the aftermath of the September 11th terror attacks. European Journal of Political Economy, 20(2), 435-446.

[18] Drakos, K. (2010). Terrorism activity, investor sentiment, and stock returns. Review of Financial Economics, 19(3), 128-135.

[19] Drakos, K., \& Kutan, A. (2003). Regional effects of terrorism on tourism in three Mediterranean countries. Journal of Conflict Resolution, 47(5), 621-641.

[20] Eldor, R., \& Melnick, R. (2004). Financial markets and terrorism. European Journal of Political Economy, 20(2), 367-386.

[21] Enders, W., Sandler, T., \& Parise, G.F. (1992). An econometric analysis of the impact of terrorism on tourism. Kyklos, 45(4), 531-554.

[22] Essaddam, N., \& Karagianis, J.M. (2014). Terrorism, country attributes, and the volatility of stock returns. Research in International Business and Finance, 31, 87-100.

[23] Frey, B., Luechinger, S., \& Stutzer, A. (2007). Calculating tragedy: assessing the costs of terrorism. Journal of Economic Surveys, 21(1), 1-24.

[24] Glosten, L.R., Jagannathan, R., \& Runkle, D.E. (1993). On the relation between the expected value and volatility of nominal excess return on stocks. Journal of Finance, 48(5), 1779-1801.

[25] Goodrich, J.N. (2002). September 11, 2001 attack on America: A record of the immediate impacts and reactions in the USA travel and tourism industry. Tourism Management, 23, 573580.

[26] Johnston, R.B., \& Nedelescu, O.M. (2006). The impact of terrorism on financial markets. Journal of Financial Crime, 13(1), 7-25.

[27] Kholaif, D. (2015). Sharm El Sheikh resorts deserted as tourists stay away. The Wall Street Journal, December $3^{\text {rd }}, 2015$. Retrieved from http:/www.wsj.com/articles/sharm-el-sheikhresorts-deserted-as-tourists-stay-away-1449157831

[28] Kollias, C., Papadaumou, S., \& Stagiannis, A. (2011). Terrorism and capital markets: the effects of the Madrid and London bomb attacks. International Review of Economics and Finance, 20(4), $532-541$.

[29] Lamoureux, C., \& Lastrapes, W. (1990). Persistence in variance, structural change and the GARCH model. Journal of Business and Economic Statistics, 8, 225-234.

[30] Lee, H.Y., Wu, H.C., \& Wang, Y.J. (2007). Contagion effect in financial markets after the SouthEast Asia Tsunami. Research in International Business and Finance, 21, 281-296.

[31] Leong, C. C., \& Hui, T. K. (2014). Macroeconomic and non-macroeconomic variables linking to Singapore hotel stock returns. In J. S. Chen (Ed.), Advances in hospitality and leisure (pp. 21-36). United Kingdom: Emerald Group Publishing Limited. 
[32] Mansfeld, Y. (1999). Cycles of war, terror, and peace: Determinants and management of crisis and recovery of the Israeli tourism industry. Journal of Travel Research, 38(1), 30-36.

[33] McAleer, M. (2014). Asymmetry and leverage in conditional volatility models. Econometrics, 2(3), 145-150.

[34] McAleer, M. (2015). The fundamental equation in tourism finance. Journal of Risk and Financial Management, 8(4), 369-374.

[35] McAleer, M., \& Hafner, C. (2014). A one line derivation of EGARCH. Econometrics, 2(2), 92 97.

[36] Nelson, D.B. (1991). Conditional heteroskedasticity in asset returns: A new approach. Econometrica, 59(2), 347-370.

[37] Nikkinen, J., \& Vähämaa, S. (2010). Terrorism and stock market sentiment. Financial Review, 45(2), 263-275.

[38] Paraskevas, A., \& Arendell, B. (2007). A strategic framework for terrorism prevention and mitigation in tourism destinations. Tourism Management, 28(6), 1560-1573.

[39] Peren, A.K., Ciferri, D., \& Spagnolo, N. (2008). The price of terror: The effects of terrorism on stock market returns and volatility. Economic Letters, 101(3), 164-167.

[40] Saha, S., \& Yap, G. (2014). The moderation effects of political instability and terrorism on tourism development: A cross-country panel analysis. Journal of Travel Research, 53(4), 509521.

[41] Sharpley, R. (2005). The tsunami and tourism: A comment. Current Issues in Tourism, 8, 344349.

[42] Smout, A. (March 22, 2016). Travel shares fall after explosions in Brussels. REUTERS. Retrieved from http://www.reuters.com/article/us-belgium-blast-stocks-idUSKCN0WO0PF

[43] Song, H., \& Li, G. (2008). Tourism demand modelling and forecasting - A review of recent research. Tourism Management, 29(2), 203-220.

[44] Sönmez, S. (1998). Tourism, terrorism and political instability. Annals of Tourism Research, 25(2), 416-456.

[45] Wearden, G., \& Allen, K. (November 16, 2015). Billions wiped off European travel shares after Paris attacks. The Guardian. Retrieved from http://www.theguardian.com/business/2015/nov/16/billions-wiped-off-european-travel-sharesafter-paris-attacks

[46] Wong, K.K.F., \& Song, H. (2006). Do macroeconomic variables contain any useful information for predicting changes in hospitality stock indices? Journal of Hospitality \& Tourism Research, 30(1), 16-33.

[47] World Tourism Organization (2014). Tourism highlights - 2014 edition. Retrieved 16 January 2015, from. http://mkt.unwto.org/publication/unwto-tourism-highlights-2014-edition

[48] Zheng, T., Farrish, J., \& Kitterlin, M. (2016). Performance trends of hotels and casino hotels through the recession: An ARIMA with intervention analysis of stock indices. Journal of Hospitality Marketing \& Management, 25(1), 49-68.

[49] Zussman, A., \& Zussman, N. (2006). Assassinations: Evaluating the effectiveness of an Israeli counterterrorism policy using stock market data. Journal of Economic Perspectives, 20(2), 193 206. 